\title{
A unique complex translocation involving six different chromosomes in a case of childhood acute lymphoblastic leukemia with the Philadelphia chromosome and adverse prognosis
}

\author{
WALID AL ACHKAR ${ }^{1}$, ABDULSAMAD WAFA $^{1}$, HASMIK MKRTCHYAN $^{2}$, \\ FATEN MOASSASS ${ }^{1}$ and THOMAS LIEHR ${ }^{2}$
}

\begin{abstract}
${ }^{1}$ Molecular Biology and Biotechnology Department, Human Genetics Division, Atomic Energy Commission of Syria, Damascus, Syria; ${ }^{2}$ Jena University Hospital, Institute of Human Genetics and Anthropology, D-07743 Jena, Germany
\end{abstract}

Received March 17, 2010; Accepted June 22, 2010

DOI: 10.3892/ol_00000140

\begin{abstract}
Acute lymphoblastic leukemia (ALL) is the most common childhood malignancy. Approximately $84 \%$ of cases of ALL are classified as B-precursor ALL, $14 \%$ of cases are T-cell and 2\% of cases are B-cell (B-)ALL. About one third of B-ALL cases show an abnormal karyotype. Combining data obtained by immunophenotyping, karyotyping and molecular cytogenetic analyses allows for a better understanding of this heterogeneous disease. This study reports an exceptional B-ALL case with a poor prognosis and unique complex chromosomal aberrations not previously observed, i.e., a translocation involving the six chromosomal regions 1q42, 4q21, 4q24, 4q35 (twice), 8q22 and 10p15.3 besides 9q34 and 22q11.2.
\end{abstract}

\section{Introduction}

Childhood acute lymphoblastic leukemia (ALL) is the most common malignancy in humans aged 18 years or younger. In a number of these children the outcome of treatment is difficult to predict and is considered to be an individual response of the patient to chemotherapy. It is likely that the observed clinical heterogeneity reflects a diverse pathogenesis of leukemia. The molecular basis of childhood ALL is to a large extent unknown, and it is likely that significant advances in the treatment of this malignancy are dependent on a better understanding of the molecular events that cause the disease $(1,2)$. A number of investigators have attempted to identify groups of genes, termed 'transcriptional signatures' whose expression can be directly associated with drug resistance (3).

Correspondence to: Dr Walid Al Achkar, Molecular Biology and Biotechnology Department, Human Genetics Division, Atomic Energy Commission of Syria, P.O. Box 6091, Damascus, Syria E-mail: ascientific@aec.org.sy

Key words: childhood B-cell acute lymphoblastic leukemia, BCR/ABL positive, chromosomal aberrations, fluorescence in situ hybridization, multicolor banding
The immunophenotypic characteristics of precursor B-cell acute lymphoblastic leukemic cells (clonal expansion of progenitors of B-cell lymphocytes) are believed to reflect normal hematopoietic B-cell precursors. However, previous studies showed that through the simultaneous acquisition of various antigens, almost all B-precursor-ALL cases display phenotypic aberrations (4-8). The latter may be associated with specific genetic abnormalities, and it has been suggested that they are useful for a better understanding of protein expression dysregulation (9). Approximately 84\% of ALL cases are B-precursor ALL, 14\% are T-cell ALL and $2 \%$ are B-cell (B-)ALL (10). At least $32 \%$ of the ALL cases show clonal chromosomal abnormalities (11). The so-called Philadelphia $(\mathrm{Ph})$ chromosome $\mathrm{t}(9 ; 22)$ is present in $4 \%$ of pediatric ALL patients and confers an unfavorable prognosis, particularly when associated with either a high whole blood cell count (WBC) or slow early response to initial therapy (12-14).

This study reported a childhood B-ALL case with unique complex aberrations and six chromosomal breakpoints. In this case, the array-proven high-resolution multicolor banding (aMCB) technique was of enormous significance for detecting the genetic changes.

\section{Materials and methods}

Case report. In May 2009, a 14-year-old male patient presented with a WBC of $123.6 \times 10 \% / 1$, i.e., $6.1 \%$ neutrophils, $65 \%$ lymphocytes, $0.1 \%$ eosinophiles, $1.2 \%$ monocytes, $5.6 \%$ basophiles and $27.6 \%$ largely unidentified cells. The platelet count was $205 \times 10^{9} / 1$ and hemoglobin $8.7 \mathrm{~g} / \mathrm{dl}$. Serum lactate dehydrogenase (LDH) was $556 \mathrm{U} / 1$ (normal: up to $480 \mathrm{U} / \mathrm{l}$ ), and the level of serum alkaline phosphates was $191 \mathrm{U} / 1$ (normal: up to $141 \mathrm{U} / \mathrm{l})$. A physical examination showed no splenomegaly, but loss of weight was noted. No response was observed after the application of two standard protocols for ALL and acute myeloid leukemia (AML). For 2 months the patient was treated with imatinib (400 mg per day). However, one month later the patient succumbed to the disease while undergoing treatment. Cytogenetics and molecular cytogenetics. Banding cytogenetics using GTG-banding was performed according to 


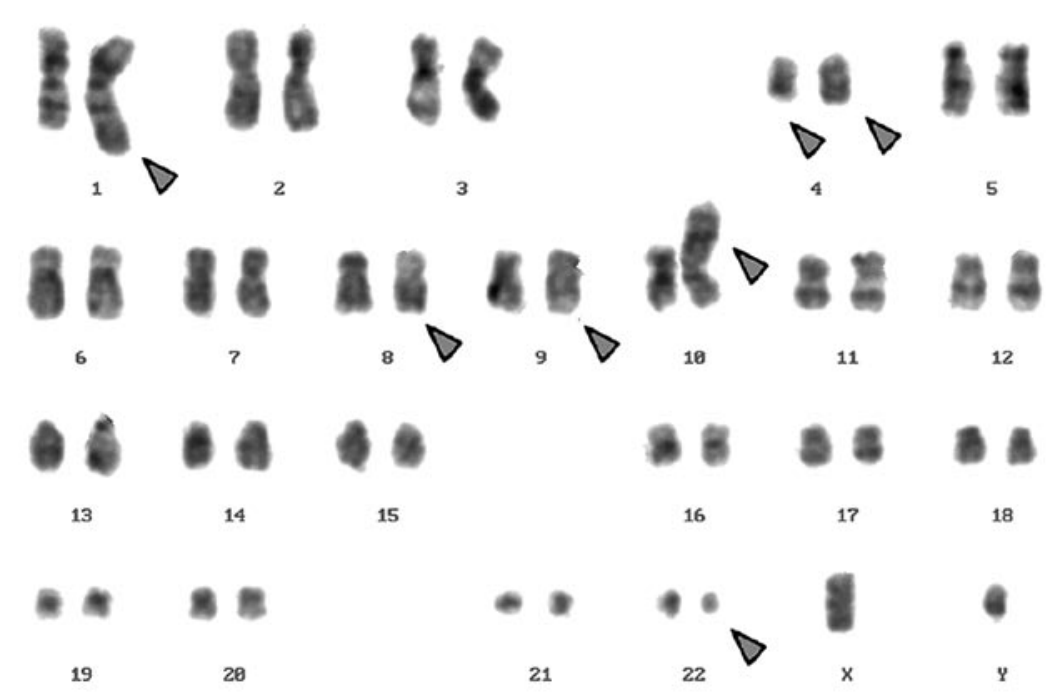

Figure 1. GTG-banding revealed a complex karyotype involving four further chromosomes besides chromosomes 9 and 22. The derivative chromosomes are indicated by the arrowheads.

standard procedures (15), and 20 metaphases derived from the unstimulated bone marrow of the patient were analyzed. Patient consent for the study was obtained.

Fluorescence in situ hybridization (FISH) using commercially available probes for BCR/ABL and subtelomeric for 10p/10q (Abbott/Vysis) were applied according to the manufacturer's instructions. High-resolution aMCB, based on microdissection-derived region-specific libraries for chromosomes 1, 4, 8 and 10, was performed as previously described; method and MCB probe sets are specified $(15,16)$. A total of 30 metaphase spreads were analyzed, each using a fluorescence microscope (AxioImager.Z1 mot, Zeiss) equipped with appropriate filter sets to discriminate between a maximum of five fluorochromes and the counterstain 4',6-diamino-2-phenylindole (DAPI). Image capturing and processing were carried out using an Isis mFISH imaging system (MetaSystems, Altlussheim, Germany) for the evaluation of MCB.

Immunophenotyping. Immunophenotyping of leukemic blasts was carried out using fluorescein isothiocyanate (FITC)- and phycoerythrin (PE)-conjugated monoclonal antibodies (BectonDickinson, Franklin Lakes, NJ, USA). Antibodies against the following antigens were used: CD34, CD45, HLA-Dr, CD117, CD10, CD4, CD7, CD8, CD19, CD38, as well as cCD13, cMPO, cTdt, cCD2, cCD3, cCD22 and cCD79a (17). Positivity (<20\%), was considered to be a negative result.

\section{Results}

Karyotyping was carried out after the initiation of chemotherapy treatment, showing certain karyotypic changes. A complex karyotype 46,XY/46,XY,der(1),del(4),der(4),t(9;22), der(10) was determined in the GTG-banding (Fig. 1) and was further studied by molecular cytogenetics (Figs. 2-4). Dualcolor-FISH using a commercially available probe specific for $\mathrm{BCR}$ and $\mathrm{ABL}$ showed that the typical Ph chromosome with BCR/ ABL translocation was present. The application of subtelomeric probes for $10 \mathrm{p}$ and $10 \mathrm{q}$ showed normal signals of subtelomeric 10p/10q on chromosome 10 . However, only subtelomeric region $10 \mathrm{q}$ was present on the derivative chromosome 10 , while subtelomeric region 10p was detected on the derivative chromosome 1 (Fig. 2). Thus, aMCB, using probes for the corresponding chromosomes involved according to GTG-banding, was performed (16). The result obtained was: 46,XY[4]/46,XY,der(1)t $(1 ; 4 ; 10)$ (1pter->1q42::4q21->4q35::10p15.3-10pter), del(4)(q24),t(9;22) (q34;q11.2), der(10)t $(8 ; 4 ; 10)(8 \mathrm{qter}->8 \mathrm{q} 22:: 4 \mathrm{q} 21->4 \mathrm{q} 35:: 10 \mathrm{p} 15.3-$ $>10$ qter) (16).

Immunophenotyping of leukemic blasts was performed using FITC- and PE-conjugated monoclonal antibodies. The blasts stained positively with CD10 (88\%), CD19 (86\%), CD79a (80\%), CD34 (86\%), CD45 (95\%) and HLA-DR (49\%). Based on these findings and using the criteria of the European Group for the Immunological Characterization of Acute Leukemia (EGIC), the patient was diagnosed as having common precursor B-cell acute lymphoblastic leukemia.

\section{Discussion}

According to the literature, $32 \%$ of ALL cases demonstrate an abnormal karyotype, either in chromosome number (ploidy) or in structural changes such as translocations, inversions, or deletions (11-12). Not infrequently, chromosomes studied in ALL exhibit a poor morphology, tend not to spread well, and appear fuzzy with indistinct margins, making banding studies challenging or even impossible (12). Nonetheless, it is known that in ALL the most common chromosomal changes are $\mathrm{t}(12 ; 21), \mathrm{t}(9 ; 22), \mathrm{t}(4 ; 11)$ and del(6q) followed by $\mathrm{t}(8 ; 14), \mathrm{t}(1 ; 19)$ and $\operatorname{del}(9 \mathrm{p})$ (18). Among the specific chromosome translocations identified and causally linked to leukemogenesis, BCR/ABL gene rearrangements are one of the best characterized rearrangements $(19,20)$. It was shown that among B-precursor-ALL patients, this translocation is present in approximately $20-30 \%$ of adult cases while it is rarely detected in children (21-27), as found in the present patient. In this case, we described unique complex translocations associated with B-ALL, including the involvement of two 


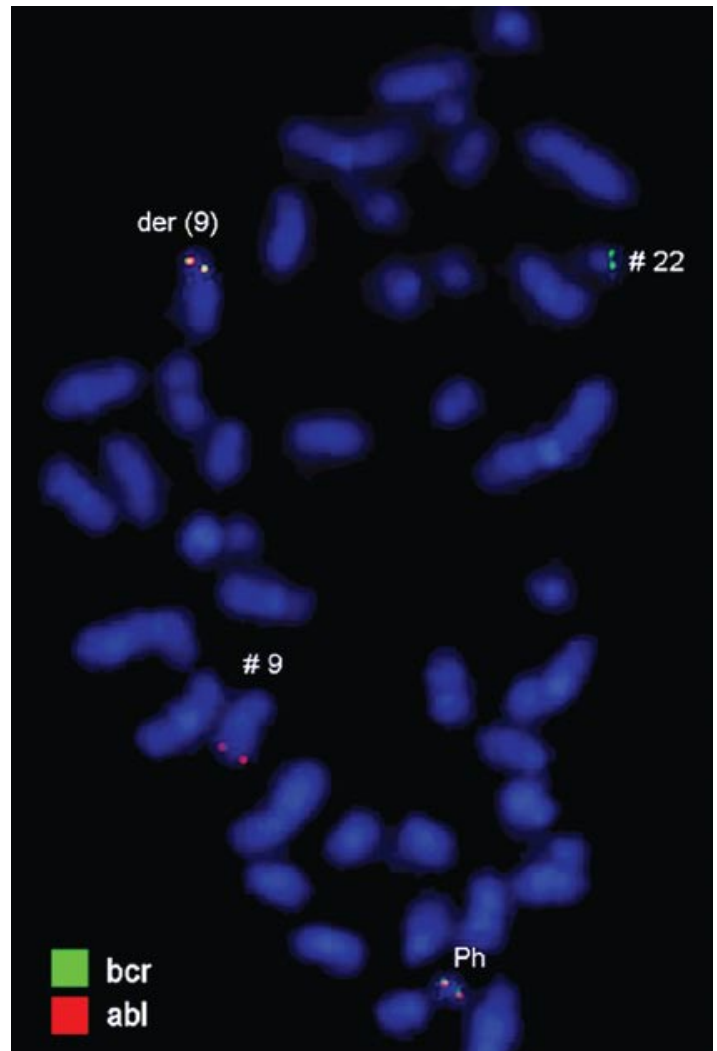

Figure 2. Fluorescence in situ hybridization (FISH) using probes for BCR (green) and ABL (red) confirmed the presence of the BCR/ABL translocation and the Philadelphia $(\mathrm{Ph})$ chromosome. \#, chromosome; der, derivative chromosome.

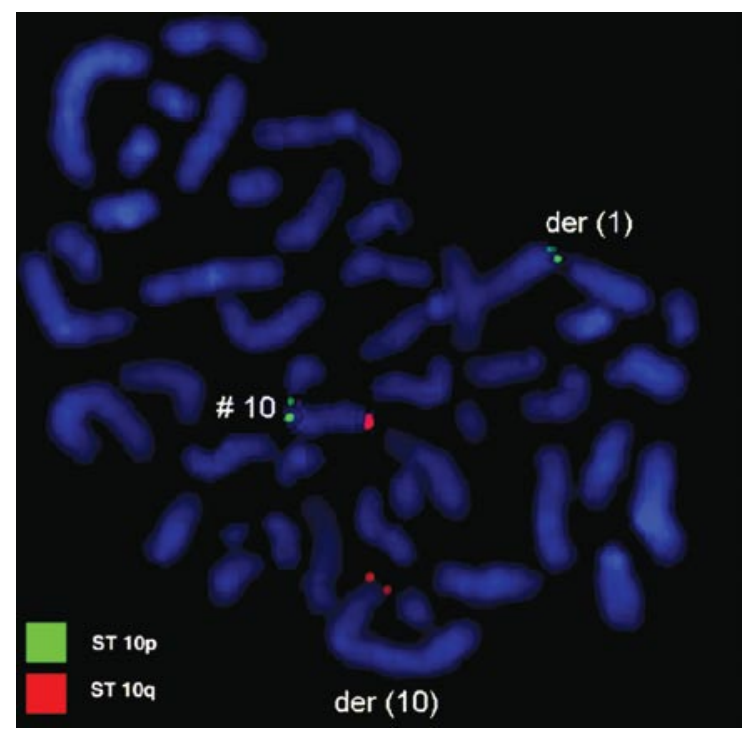

Figure 3. Fluorescence in situ hybridization (FISH) using probes for subtelomeric 10p (green) and 10q (red) confirmed involvement of chromosome 1 in the rearrangement present in this case. \#, chromosome; der, derivative chromosome.

chromosomes 4 in complex translocations, in addition to the $\mathrm{t}(9 ; 22)(\mathrm{q} 34 ; \mathrm{q} 11.2)$. The lymphatic marker CD10 was also expressed. The patient did not respond to the standard

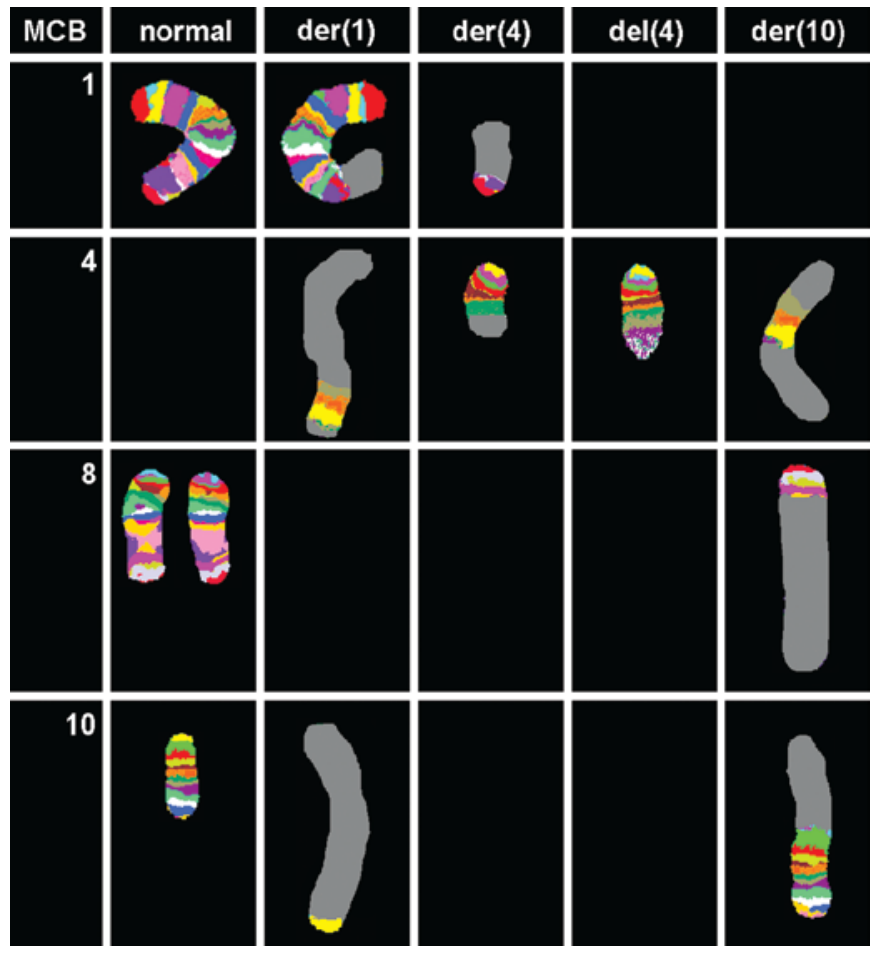

Figure 4. Array-proven multicolor banding (aMCB) was applied to determine the involvement in this complex rearrangement. Each lane shows the results of aMCB analysis using probe-sets for chromosomes 1, 4, 8 and 10. The normal chromosomes are shown in the first column, and the derivative of the four chromosomes in the subsequent ones. The aMCB-probe unstained regions on the derivative chromosomes are shown in gray.

chemotherapy protocols suggested by large prospective studies on childhood ALL $(30,31)$, and the cytogenetic investigation after six months of chemotherapy treatment showed the aforementioned chromosomal abnormalities.

B-lineage, defined by the expression of CD19, HLA-DR, CD10 (cALLa) and other B-cell-associated antigens are observed in $80-85 \%$ of childhood ALL. Approximately $80 \%$ of B-precursor ALL cases express the cALLa, CD10 antigen (18). Thus, the observed immunophenotype of the reported case was appropriate to this group and aided in the identification of the type of malignancy present.

One study reported that the pattern of expression of a set of genes can determine resistance to common chemotherapeutic agents (3). This study identified 45 genes differentially expressed between resistant and sensitive ALL samples whose expression pattern was significantly related to treatment response (28). The 45 genes were involved in the regulation of transcription, cellular transport and cell cycle maintenance. Using patterns of gene expression, the authors were able to distinguish a subgroup of ALL tumors with cross-chemoresistance and unfavorable outcome from those which exhibited only single-drug resistance. The same study also showed that transcriptional regulation of key apoptosis genes can be linked to cellular drug resistance and prognosis in pediatric B-lineage ALL (29). The present case may reflect the same manner of drug-resistance due to the large number of chromosome breaks and aberrations involved. 
Therefore, the observed complex karyotype, along with the $\mathrm{Ph}$ chromosome is a poor prognostic factor in B-ALL patients, since no response was observed after the application of two standard treatment protocols for ALL and AML.

\section{Acknowledgements}

We would like to thank Professor Ibrahim Othman, the Director General of the Atomic Energy Commission of Syria (AECS) and Dr Nizar MirAli, Head of the Molecular Biology and Biotechnology Department, for their support. This study was partially supported by the AECS, by the StefanMorsch-Stiftung, Monika-Kutzner-Stiftung and the DAAD (D/07/09624).

\section{References}

1. Endo C, Oda M, Nishiuchi R and Seino Y: Persistence of TEL-AML1 transcript in acute lymphoblastic leukemia in long-term remission. Pediatr Int 45: 275-280, 2003.

2. McLean TW, Ringold S, Neuberg D, Stegmaier K, Tantravahi R, Ritz J, Koeffler HP, Takeuchi S, Janssen JW, Seriu T, Bartram CR, Sallan SE, Gilliland DG and Golub TR: TEL-AML1 dimerizes and is associated with a favorable outcome in childhood acute lymphoblastic leukemia. Blood 88: 4252-4258, 1996.

3. Holleman A, Cheok MH, den Boer ML, Yang W, Veerman AJ, Kazemier KM, Pei D, Cheng C, Pui CH, Relling MV, JankaSchaub GE, Pieters R and Evans WE: Gene-expression patterns in drug-resistant acute lymphoblastic leukemia cells and response to treatment. N Engl J Med 351: 533-542, 2004.

4. Ong ST and Larson RA: Current management of acute lymphoblastic leukemia in adults. Oncology 9: 433-442, 1995.

5. Campana D and Pui CH: Detection of minimal residual disease in acute leukemia: methodologic advanced and clinical significance. Blood 85: 1416-1434, 1995.

6. Ciudad J, San Miguel JF, López-Berges MC, Vidriales B, Valverde $B$, Ocqueteau M, Mateos G, Caballero MD, Hernández J, Moro MJ, Mateos MV and Orfao A: Prognostic value of immunophenotypic detection of minimal residual disease in acute lymphoblastic leukemia. J Clin Oncol 16 3774-3781, 1998.

7. Orfao A, Schmitz G, Brando B,. Ruiz-Arguelles A, Basso G, Braylan R, Rothe G, Lacombe F, Lanza F, Papa S, Lucio P and San Miguel JF: Clinically useful information provided by the flow cytometric immunophenotyping of hematological malignancies: current status and future directions. Clin Chem 45: 1708-1717, 1999

8. Orfao A, Ciudad J, Almeida J and San Miguel JF: Residual disease detection of leukemia. In: Immunophenotyping. Stewart CC and Nicholson JKA (eds). Wiley-Liss, New York, pp239-259, 2000.

9. Tabernero MD, Bortoluci AM, Alaejos I, López-Berges MC, Rasillo A, García-Sanz R, García M, Sayagués JM, González M, Mateo G, San Miguel JF and Orfao A: Adult precursor B-ALL with BCR/ABL gene rearrangements displays a unique immunophenotype based on the pattern of CD10, CD34, CD13 and CD38 expression. Leukemia 15: 406-414, 2001.

10. Camitta BM, Pullen J and Murphy S: Biology and treatment of acute lymphocytic leukemia in children. Oncology 24: 83-91, 1997.

11. Martinez-Climent JA: Molecular cytogenetics of childhood hematological malignancies. Leukemia 11: 1999-2021, 1997.

12. Hann I, Vora A, Harrison G, Harrison C, Eden O, Hill F, Gibson B and Richards S: UK Medical Research Council's Working Party on Childhood Leukaemia: Determinants of outcome after intensified therapy of childhood lymphoblastic leukaemia: results from Medical Research Council United Kingdom Acute Lymphoblastic Leukaemia XI Protocol. Br J Haematol 113: 103-114, 2001.

13. Aricò M, Valsecchi MG, Camitta B, Schrappe M, Chessells J, Baruchel A, Gaynon P, Silverman L, Janka-Schaub G, Kamps W, Pui $\mathrm{CH}$ and Masera G: Outcome of treatment in children with Philadelphia chromosome-positive acute lymphoblastic leukemia. N Eng J Med 342: 998-1006, 2000.
14. Schrappe M, Aricò M, Harbott J, Biondi A, Zimmermann M, Conter V, Reiter A, Valsecchi MG, Gadner H, Basso G, Bartram CR, Lampert F, Riehm H and Masera G: Philadelphia chromosome-positive $\left(\mathrm{Ph}^{+}\right)$childhood acute lymphoblastic leukemia: good initial steroid response allows early prediction of a favorable treatment outcome. Blood 92: 2730-2741, 1998.

15. Liehr T, Heller A, Starke H, Rubtsov N, Trifonov V, Mrasek K, Weise A, Kuechler A and Claussen U: Microdissection-based high resolution multicolor banding for all 24 human chromosomes. Int J Mol Med 9: 335-339, 2002.

16. Weise A, Mrasek K, Fickelscher I, Claussen U, Cheung SW, Cai WW, Liehr T and Kosyakova N: Molecular definition of high-resolution multicolor banding probes: first within the human DNA sequence anchored FISH banding probe set. J Histochem Cytochem 56: 487-493, 2008.

17. Mesquita DR, Córdoba JC, Magalhães IQ, Córdoba MS, Oliveira JRC, Gonçalves A, Ferrari I and Martins-de-Sá C: Molecular and chromosomal mutations among children with B-lineage lymphoblastic leukemia in Brazil's Federal District. Genet Mol Res 8: 345-353, 2009.

18. Reaman GH, Sposto R, Sensel MG, Lange BJ, Feusner JH, Heerema NA, Leonard M, Holmes EJ, Sather HN, Pendergrass TW, Johnstone HS, O'Brien RT, Steinherz PG, Zeltzer PM, Gaynon PS, Trigg ME and Uckun FM: Treatment outcome and prognostic factors for infants with acute lymphoblastic leukemia treated on two consecutive trials of the Children's Cancer Group. J Clin Oncol 17: 445-455, 1999.

19. Rowley JD: Molecular genetics in acute leukaemia. Leukemia 14: 513-517, 2000

20. Sánchez-García I and Grütz G: The tumorigenic activity of the BCR-ABL oncogenes is mediated by BCL-2. Proc Natl Acad Sci USA 92: 5287-5291, 1995.

21. Rieder H, Bonwetsch C, Janssen LA, Maurer J, Janssen JW, Schwartz S, Ludwig WD, Gassman W, Bartram CR, Thiel E, Loffler H, Gokbuget N, Hollzer D and Fonatsch C: High rate of chromosome abnormalities detected by fluorescence in situ hybridization using BCR and ABL probes in adult acute lymphoblastic leukemia. Leukemia 12: 1473-1481, 1998.

22. Copelan EA and McGuire EA: The biology and treatment of acute lymphoblastic leukemia in adults. Blood 85: 1151-1168, 1995.

23. Secker-Walker LM, Craig JM, Hawkins JM and Hoffbrand AV: Philadelphia positive acute lymphoblastic leukaemia in adults age distribution, BCR breakpoint and prognostic significance. Leukemia 5: 196-199, 1991.

24. Annino L, Ferrari A, Cedrone M, Giona F, Lo Coco F, Meloni G, Arcese W and Mandelli F: Adult Philadelphia-chromosomepositive acute lymphoblastic leukaemia: experience of treatments during a 10-year period. Leukemia 8: 664-667, 1994.

25. Secker-Walker LM, Pentrice HG, Durrant J, Richards S, Hall E and Harrison G: Cytogenetics adds independent prognostic information in adults with acute lymphoblastic leukaemia on MRC trial UKALL XA. Br J Haematol 96: 601-610, 1997.

26. Pui CH, Crist WM and Look T: Biology and clinical significance of cytogenetic abnormalities in childhood acute lymphoblastic leukaemia. Blood 76: 1449-1463, 1990.

27. Pui $\mathrm{CH}$ and Evans WE: Acute lymphoblastic leukemia. N Engl J Med 339: 605-615, 1998.

28. Lugthart S, Cheok MH, den Boer ML, Yang W, Holleman A, Cheng C, Pui CH, Relling MV, Janka-Schaub GE, Pieters R and Evans WE: Identification of genes associated with chemotherapy crossresistance and treatment response in childhood acute lymphoblastic leukemia. Cancer Cell 7: 375-386, 2005.

29. Holleman A, den Boer ML, de Menezes RX, Cheok MH, Cheng C, Kazemier KM, Janka-Schaub GE, Göbel U, Graubner UB, Evans WE and Pieters R: The expression of 70 apoptosis genes in relation to lineage, genetic subtype, cellular drug resistance, and outcome in childhood acute lymphoblastic leukemia. Blood 107: 769-776, 2006.

30. Nyvold C, Madsen HO, Ryder LP, Seyfarth J, Svejgaard A, Clausen N, Wesenberg F, Jonsson OG, Forestier E, Schmiegelow K and Nordic Society for Pediatric Hematology and Oncology: Precise quantification of minimal residual disease at day 29 allows identification of children with acute lymphoblastic leukemia and an excellent outcome. Blood 99: 1253-1258, 2002.

31. Lal A, Kwan E, Haber M, Norris MD and Marshall GM: Detection of minimal residual disease in peripheral blood prior to clinical relapse of childhood acute lymphoblastic leukaemia using PCR. Mol Cell Probes 15: 99-103, 2001. 